\title{
Application of a topographic pedosequence in the Villány Hills for terroir characterization
}

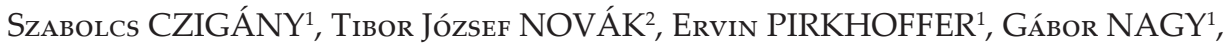 \\ Dénes LÓCZY ${ }^{1}$, József DEZSŐ' ${ }^{1}$, Szabolcs Ákos FÁBIÁN ${ }^{1}$, MARCin ŚWITONIAK $^{3}$ and \\ PRZEMYSLAW CHARZYNSSKI ${ }^{3}$
}

\begin{abstract}
Terroir refers to the geographical origin of wines. The landscape factors (topography, parent rock, soil, microbial life, climate, natural vegetation) are coupled with cultural factors (cultivation history and technology, cultivars and rootstock) and all together define a terroir. The physical factors can be well visualized by a slope profile developed into a pedosequence showing the regular configuration of the relevant physical factors for a wine district. In the present study the generalized topographic pedosequence (or catena) and GIS spatial model of the Villány Hills, a historical wine producing region, serves for the spatial representation and characterization of terroir types. A survey of properties of Cabernet Franc grape juice allowed the comparison of 10 vineyards in the Villány Wine District, Southwest Hungary. Five grape juice properties (FAN, $\mathrm{NH}_{3}, \mathrm{YAN}$, density and glucose + fructose content) have been found to have a moderate linear relationship $\left(0.5<r^{2}<0.7\right)$ with the Huglin Index $(H I)$ and aspect. Aspect, when determined on the basis of angular distance from South $\left(180^{\circ}\right)$, showed a strong correlation $\left(r^{2}>0.7\right)$ with FAN, $\mathrm{NH}_{3}$, YAN, sugar and density and moderate correlation with primary amino nitrogen (PAN). HI showed a correlation with three nitrogen related parameters FAN, $\mathrm{NH}_{3}, \mathrm{YAN}$, density and glucose + fructose content. Elevation and slope, however, did not correlate with any of the chemical properties.
\end{abstract}

Keywords: pedosequence, GIS, terroir, soils, grape juice properties, Huglin Index

Received: February 2020; Accepted May 2020.

\section{Introduction}

The concept of terroir is widely used to explain the unique quality of agricultural products, first of all, of wines. Terroir refers to the geographical origin of wine, the particular interaction of ecosystem factors, including local rocks, topography, climate, soil and others (BiancotTi, A. 2003; Vaudour, E. et al. 2005; Gladstones, J. 2011; Fraga, H. et al. 2014). The biophysical factors are combined with cultural elements (cultivation history, cultivars and rootstocks, viticultural and oenological techniques etc.) to produce a wine of individual character (SEguin, G. 1986; Unwin T. 2012). The usefulness of the terroir concept has been recently supported by GIS tools (BALLA, D.Z. et al. 2019) whereas its applicability is also confirmed by its rapid spreading from Europe (e.g. FALCETTI, M. 1994; WiLson, J. 1998) to all other continents where grapes are grown (JACKsON, D. and Lombard, P. 1993; e.g. in Canada: Haynes, S.J. 2000; in South Africa: Wooldridge, J. 2000; in Australia: Halliday, J. 2007). The terroir may be an elusive term sometimes but it provides a very stable background to grapes and wine production. JACKsON, D.

\footnotetext{
${ }^{1}$ Institute of Geography and Earth Sciences, University of Pécs, H-7624 Pécs, Ifjúság útja 6. Hungary. E-mails: czigany@gamma.ttk.pte.hu, pirkhoff@gamma.ttk.pte.hu, gnagy@gamma.ttk.pte.hu, loczyd@gamma.ttk.pte.hu, dejozsi@gamma.ttk.pte.hu, smafu@gamma.ttk.pte.hu

${ }^{2}$ Department of Landscape Protection and Environmental Geography, University of Debrecen, H-4000 Debrecen, Egyetem tér 1. Hungary. E-mail: novak.tibor@science.unideb.hu

${ }^{3}$ Nicolaus Copernicus University in Toruń, ul. Gagarina 11, 87-100 Toruń, Poland. E-mails: swit@umk.pl, pecha@umk.pl
} 
and Lombard, P. (1993) underline that it is mainly the concept of terroir that explains how the appellations of the French wine districts could maintain their quality over centuries. In those districts a huge collective knowledge has accumulated on the interactions between the biophysical environment and the practices applied in vitiviniculture (VVC) which is recognizable in the quality of wine (OIV 2008). The terroir concept also extends to the landscape transformation caused by grapevine cultivation, its literary and fine arts reflections and is used in wine marketing strategies (VAudour, E. 2001; Jordán, GY. et al. 2005; Szilassi, P. et al. 2006).

Although it is impossible to define the ideal climate (temperature, rainfall amount and regime or solar radiation) and the best possible soil for vine growing and wine production, all these complex factors have to be considered in their interactions when terroir is described and assessed (vAn LeEuwEn, C. and SEguin, G. 2006; van Leeuwen 2010; Ferretti, C.G. 2019). The complex interactions explain why the terroir is a typically holistic concept (MALHEIRo, A.C. et al. 2010; Fraga, H. et al. 2018).

Topography (slope conditions) is a fundamental component of the terroir as it influences the distribution of parent rock outcrops, some physical and chemical properties of soils and slope deposits, microclimate and natural vegetation (FrAGA, H. et al. 2014). Elevation, slope angle and aspect are equally influential (JonEs, G.V. 2004). Even a $100 \mathrm{~m}$ difference in elevation between the top and bottom of the slope may reflect variation within the terroir of the same vineyard plot. Slope inclination and aspect impact on radiation balance, soil erosion, drainage and management (Zsófi, Zs. et al. 2011). Where steep slopes require terracing (Šmid Hribar, M. et al. 2017), the artificial slope form leads to a fundamental transformation of the terroir.

Among soil parent materials, limestone (the rock building the Villány Hills) has a good nutrient supply to grapes, good drainage but retains moisture under dry weather conditions. There is a single negative effect of carbonates: they cause iron deficiency in grapes (Tagliavini, M. and Rombolà, A.D. 2001). Calcareous soils support excellent blends like Aube in Champagne, Chablis in Burgundy, Pouilly and Sancerre in the Loire Valley and Côtes du Rhône in the Lower Rhône Valley (WiLson, J. 1998).

Physical and chemical soil properties influence grapevine growth and eventually wine quality (Mackenzie, D.E. and Christy, A.G. 2005; QI, Y.B. et al. 2019). Good wines are produced on a wide range of soils (WANG, R. et al. 2015; WARMLING, M.T. et al. 2018) and soil texture may vary from skeletal soils to those with 60 per cent clay (SEguIN, G. 1986). Grape juice properties are clearly correlated with plantavailable trace elements $(\mathrm{Ca}, \mathrm{Sr}, \mathrm{Ba}, \mathrm{Pb}$ and $\mathrm{Si}$ ) in the soil (MACKenzIE, D.E. and Christy, A.G. 2005). If water supply and nitrogen availability are limited, vine vigour, berry weight and yield decline, while sugar content, anthocyanin and tannin concentrations increase in berries (Matthews, M. and Anderson, M. 1988, 1989; Choné, X. et al. 2001; Hilbert, G. et al. 2003). These 'deficiencies' in soil properties are beneficial to grape quality potential for red wine making. On the other hand, insufficient soil depth and soil compaction hinder moisture storage, root growth and aeration (JACKSON, D.I. and LombARD, P.B. 1993). In the Villány Hills the loess mantle compensates for shallow soil depth, but low soil water storage capacity is a risk factor in a region under Mediterranean influence, manifested in increasing heat and water stress (TARDAGUILA, J. et al. 2011). The microbiome in vineyards interacts with the host vine stock, there is a symbiotic relationship between soil and the microbes, which release nutrients from the soil, fix nitrogen, mitigate environmental stresses (drought or toxic contaminants) (GILBERT, J.A. et al. 2014). Each wine district (or even terroir) has its own microbial communities which indirectly influence grapes and wine quality (BArAtA, A. et al. 2012).

Topographic and soil variations among terroir units can be best demonstrated on topographic pedosequences. Supplemented with the visualization of GIS data the catena is suitable to indicate microclimate, therefore pre- 
senting soils as one of the major components of the terroir (FraGA, H. et al. 2014). When soils are considered as integral parts of terroir, then specific terroir units can be more closely related to viticultural data, as well as must properties (Vaudour, E. 2002, 2003; Deloire, A. et al. 2005; Bramley, R. and Hamilton, R. 2007).

Climatic factors limit the geographical distribution of grapevine growing and wine vigour and the distribution of white and red wines are also related to topographic, soil and climatic conditions (FraGA, H. et al. 2013). The Winkler Index defines the climatic conditions suitable for grapevine cultivation classifying the climate of wine-producing regions based on heat summation or growing degree-days (WINkLER, A.J. 1974). Its modified version, the Huglin Index (Huglin, P. 1986), is based on the temperature sum over the temperature threshold of $10{ }^{\circ} \mathrm{C}$ for all days from beginning of April to end of September. The Plant Cell Density Index (PCD) is the ratio of reflected infrared (NIR) to red light (R) (PCD $=\mathrm{NIR} / \mathrm{R})$ gives a surrogate measure of vine vigour (HALL, A. et al. 2002).

Plant protection measures are also site property dependent. Topography influences the occurrence of and damage by some fungi. Interpreting abiotic site factors, new advisory platforms give guidance and end-user information for phytosanitary decision-making including predictions of infection risks for key pathogens identified by satellites and terrestrial radar systems and precisely located by GPS (see e.g. GABEL, B. 2019).

In landscape ecology, the consequences of land use changes are also studied along catenas and for individual terroirs (JoRDán, GY. et al. 2005; Lóczy, D. and NyizsAlovszKI, R. 2005; Szilassi, P. et al. 2006; NovÁк, T.J. et al. 2014).

The paper attempts to prove that the toposequence concept is a correct methodological approach to spatial modelling of the terroir. A soil catena was first explicitly described by Milne, G. (1935) and his colleagues in East Africa in the 1930s (Borden, R.W. et al. 2020). The catena became widely adopted in and beyond soil science. Now it is used by ecologists, geomorphologists and hydrologists amongst others. In a modern interpretation the catena indicates spatial patterns of soil and vegetation consistently located in specific topographic positions and is used synonymous with 'toposequence' (BAsKAN, O. et al. 2016). The simplicity, appeal and longevity of the catena concept (RADWANSKI, S.A. and Ollier, C.D. 1959; Ollier, C.D. et al. 1969) makes it suitable for the integration of interdisciplinary research in geomorphology, soil science, hydrology, environmental history and other disciplines related to landscape studies.

Recently, several terroirs have been identified in the Villány Wine District: Jammertal, Csillag-völgy (Sterntal), Remete (Einsiedler), Ördög-árok (Teufelsgraben), Kopár. The differences between their natural potentials for grapes cultivation largely depend on their position on the toposequence.

The objectives of the present study were to interpret a typical pedosequence revealing a regular geographical pattern of environmental factors (slope parameters, parent material, soils, microclimate, natural vegetation etc.) for the characterization of the terroir. The Villány Hills, selected for investigation, is a well-defined wine district with a relatively simple geology and geomorphology. Therefore, a single typical topo-pedosequence is able to represent the configuration of geographical terroir factors (SWITONIAK, M. et al. 2017; CzigánY, Sz. et al. 2018).

Although a single parameter of grape juice or wine cannot comprehensively characterize a terroir, we attempt to reveal variations in nutrition properties of grapes from different vineyards of the Villány Wine District. In 2018 and 2019 the local producers of Cabernet Franc, a variety getting increasingly popular in the region, agreed to harvest grapes at the same date and to use the same technology in wine making. The objective of the present paper is to compare the impact of the physical environment on wines from 10 plots in different locations and to draw correlations between the topographic parameters of vineyards and the nutritional properties of their produces. The paper is not aimed at establishing a ranking among the studied terroirs. 


\section{Study areas}

\section{Location}

The Villány Wine District extends over various altitudinal regions of the Villány Hills, SW-Hungary (Figure 1), stretching ca. $30 \mathrm{~km}$ in an east-western direction from the village of Hegyszentmárton to the small town of Villány (Figure 2).

\section{Lithology and topography}

The Villány Hills form the southernmost hill range in Hungary. The hills are predominantly built up of Triassic, Jurassic and Cretaceous limestones and dolomites, covered by Pleistocene loess at lower elevations (Lovász, Gy. and WeIn, Gy. 1974; Lovész, Gy. 1977). In summits of the eastern and western ends limestone and dolomite commonly outcrop (WEIN, GY. 1967). The range constitutes of uplifted and imbricated horsts. The sedimentary rocks that form the bulk of the range were thrust on each other in a thrust fault style forming blocks or 'shingles' (Dezső, J. et al. 2004; SeBe, K. 2017). The blocks are bordered by fault lines that dip to the West (LovÁsz, Gy. 1977). The blocks are tilted to the West or Northwest, in the case of the Csarnóta block to the South and in the Szársomlyó block to the North. Additional Mesozoic horsts and outcrops are found in the southern foreground of the range including the Siklós Castle Hill, the Beremend Hill and the Kistapolca Hill (CZigánY, Sz. 1997). The summit regions are covered by shallow loess-like sediments and soils in a discontinuous fashion, while limestone caverns are filled in by Pliocene red clay (Lovász, Gy. 1973).

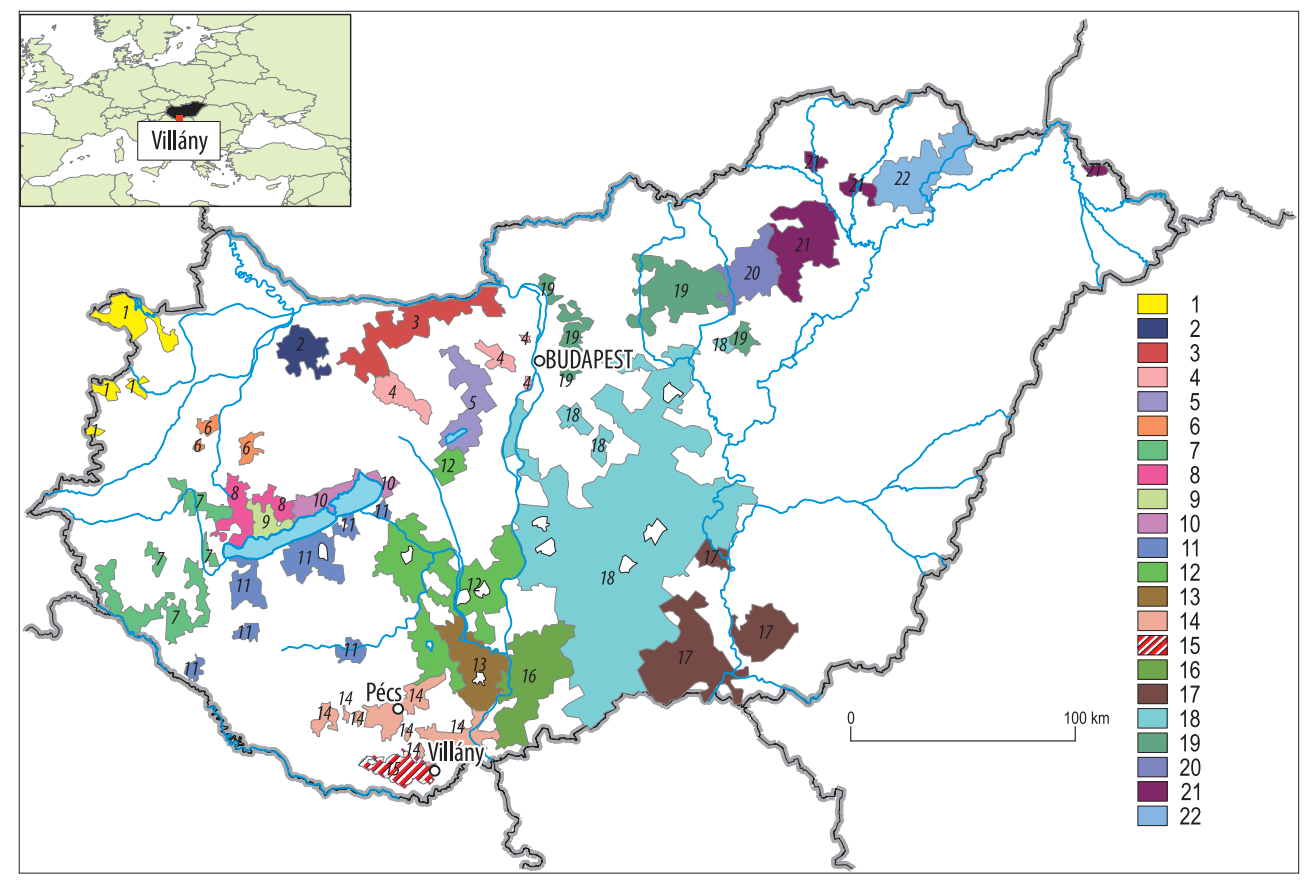

Fig. 1. Location of the Villány Wine District (no 15) in Hungary. Wine districts: 1 = Sopron; 2 = Pannonhalma; 3 = Neszmély; 4 = Mór; $5=$ Etyek-Buda; $6=$ Somló; $7=$ Zala; $8=$ Balaton Highland; $9=$ Badacsony; 10 = Balatonfüred-Csopak; 11 = Balatonboglár; 12 = Tolna; 13 =Szekszárd; 14 = Pécs; 15 = Villány; 16 = HajósBaja; 17 = Csongrád; 18 = Kunság; $19=$ Mátra; 20 = Eger; 21 = Bükk; $22=$ Tokaj 


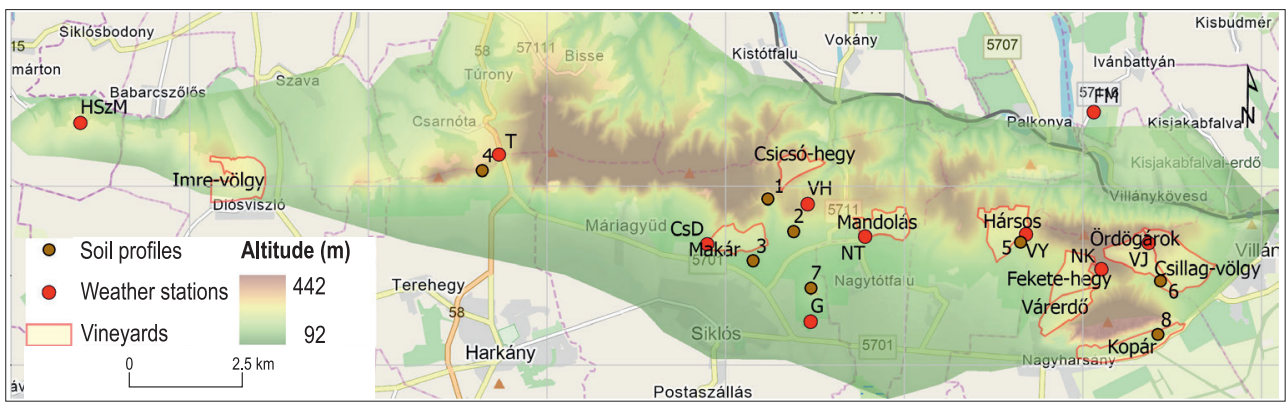

Fig. 2. Map of the Villány Wine District with locations of the studied vineyards, soil profiles and meteorological stations. Soil profiles: 1 = Melegmál; 2 = Városihegy-dülő; 3 = Zuhánya-dülő; 4 = Kopasz Hill, Csarnóta; 5 = Feketehegy, Vylyan vineyard; 6 = Ördögárok; 7 = Göntér; $8=$ Kopár. Meteorological stations: HSzM= Hegyszentmárton; $\mathrm{T}$ = Túrony; CsD = Csukma-dúlö; VH = Városi-hegy; NT = Nagytótfalu; G = Göntér; VY = Vylyan winery; FM = Fáni-major (not used for meteorological analysis); NK = Nagyharsány-Konkoly; VJ = Villány-Jammertal (Background: OpenStreet Map/ArcGIS, 5-meter DEM)

The highest point of the westernmost block is $268 \mathrm{~m}$ (Kopasz Hill). Here the limestone is extensively found on the surface and exposed in the Csarnóta Limestone Quarry. The average height of the block to the East (Csukma block) is around $340 \mathrm{~m}$ with Tenkes Hill (408 m), which is the second highest peak in the entire range. The summit elevation then decreases to about $240 \mathrm{~m}$ in the central, lowest part of the range (Város Hill block) North of the town of Siklós. Here, in this block, the consolidated bedrocks (limestones and dolomites) are only exposed in road cuts, gullies and ravines. To the East the range again gains height (Fekete Hill, $358 \mathrm{~m}$ ). The highest point of the hills is Szársomlyó (442 m). The Ördögszántás ('Devil's ploughfield') is a lapiés field carved on the faces of the north-dipping limestone strata on the southern slopes of Szársomlyó Hill. Here loess only covers the northern and the southern foothills (Lovász, Gy. and Wein, Gy. 1974; CZIGÁNY, Sz. 1998).

\section{Vegetation and land use}

There is a pronounced mesoclimatic and vegetational contrast between the southern and northern slopes. The loess-covered northern slopes and summit regions are dominated by silver lime (Tilia tomentosa), hornbeam (Carpinus betulus), pedunculate oak (Quercus robur), Turkey oak (Quercus cerris) and locally by beech (Fagus sylvatica). The natural vegetation on the southern slopes is a xerothermic wooded grassland on karst spotted with sparse rocky grasslands (BorHidi, A. and DéNES, A. 1997). A typical Mediterranean karstic steppe is found on the limestone surface of the southern slopes of the Szársomlyó Hill, with downy oak (Quercus pubescens), South European flowering/manna ash (Fraxinus ornus) and invasive tree of heaven (Ailanthus altissi$m a)$. The loess-covered southern hillslopes are used as vineyards (Tengler, T. 1997). The dirt roads leading to the vineyards have developed into sunken lanes which built alluvial fans of loess deposits at the base of slope (CZIGÁNY, Sz. 1997; Czigány, Sz. and Nagyváradi, L. 2000).

\section{Climate}

The region is located in the semi-humid temperate zone with hot summers (Lovász, GY. 1977; Коттек, M. et al. 2006), ustic soil moisture and mesic temperature regimes according to 
the USDA's Soil Taxonomy. Mediterranean and arid continental influences are also present. Mean annual temperature is $10.8^{\circ} \mathrm{C}$ (for $1971-2000$, recently 12.0 to $13.2^{\circ} \mathrm{C}$ ) and average temperature of the coldest month (January) is $-0.5^{\circ} \mathrm{C}$, while the warmest month is July with mean temperature of $22.5^{\circ} \mathrm{C}$. The average annual precipitation total is around $680 \mathrm{~mm}$ in the region. The 30-year average value is $661 \mathrm{~mm}$ for the town of Siklós, $684 \mathrm{~mm}$ for Nagytótfalu, $694 \mathrm{~mm}$ for Villány, and $701 \mathrm{~mm}$ for the town of Harkány (1971-2000 data, Hungarian Meteorological Service, OMSz). Based on the 1981 to 2010 meteorological record, February is the driest (32 mm), while the highest precipitation $(83 \mathrm{~mm})$ is recorded in June (Вӧткӧs, T. 2006).

\section{Methods}

\section{Soil sampling}

Four representative soil profiles were excavated along the southern slopes of the Villány Hills from the ridge to the southern foothill position and further four profiles were used for verification. Profiles were manually excavated to a depth of about $120 \mathrm{~cm}$ or to the depth of the parent material. Profile locations were selected according to slope position, parent material and land use. Soil profiles were described and classified: master and diagnostic horizons were determined according to the WRB (World Reference Base for Soil Resources; Guidelines for soil description by FAO 2006; IUSS Working Group 2015;). Munsell color, field moisture conditions and soil structure of each horizon were determined in the field.

Disturbed soil samples were then taken from the centre of each horizon and were analysed in the laboratories of University of Pécs and University of Debrecen for particle size distribution. Particle size distribution was determined using a MasterSizer 3000 (Malvern Inc. Malvern, United Kingdom) particle size analyser, and combined wet sieving (2.0-0.2 mm fractions) and the pipette method $(<0.2 \mathrm{~mm}$ fractions) (PAnsu, M. and Gatheyrou, J. 2006).

\section{Spatial visualization of climate data}

Climate data were obtained from 9 meteorological stations, maintained by the Tenkes Wine Region Management Corporation (see Figure 2). Sensors of the stations were manufactured by the Boreas Ltd. (Érd, Hungary). Weather data included air temperature, precipitation, insolation, relative humidity, wind speed and wind direction. Only the year 2013 was devoid of hiatus, hence it was selected for the calculation of the Huglin Index $(H I)$, used for the evaluation of climatic influences on terroir properties. Eventually, $\mathrm{HI}$ is a method for classifying the climate of wine growing regions based on heat summation of growing degree-days (Huglin, P. 1986). The index assumes that growth of the grape plant begins when daily mean temperature reaches $10^{\circ} \mathrm{C}$ in the spring and was calculated for the days when the 5-day moving average of daily mean temperatures reached a minimum of $10^{\circ} \mathrm{C}$ (growing season) with the following equation:

$$
H I=\frac{T_{\min }+T_{\max }-20}{2} \text {, }
$$

where $T_{\min }$ and $T_{\max }$ are the daily minimum and maximum temperatures during the growing season, respectively.

All point weather data were then interpolated and weighted according to the 2013 raster based insolation GIS database of the area. Correlation between the incoming solar radiation of the nine weather stations and HI was calculated by fitting a linear trend line on the corresponding data in a form of $y=a x+b$. (The actual equation is $y=0.0033 x-1,813$.2.) Derived temperature data were further weighted as a function of vertical elevation gradient at a rate of $0.65{ }^{\circ} \mathrm{C}$ decrease of temperature for each $100 \mathrm{~m}$ elevation increment. All raster calculations were done in ArcGIS Pro software environment.

\section{Vitivinicultural data and statistical analyses}

Ten vineyards were selected for verification purposes of the terroir-catena approach model (see Figure 2). Tartaric acid, malic acid, pH, 
primary amino nitrogen (PAN), free amino nitrogen (FAN), $\mathrm{NH}_{3}$ content, yeast assimilable nitrogen (YAN), density, ${ }^{\circ}$ Brix and sugar content (glucose + fructose) of Cabernet Franc grape juice, obtained from vintners, were used for model verification. Correlation coefficients $\left(r^{2}\right)$ using linear relationships were then determined between the vitivinicultural (VVC) properties and the factors influencing terroir properties (HI, elevation, slope inclination and aspect). Anova statistics and cluster analysis were run using PAST 2.0 software for the must properties of each vineyard.

\section{Results and discussion}

\section{Soil genesis and systematic position}

The investigated soil profiles exhibit a high diversity of soils. The pedosequence represents a typical series of soils starting from the summit, covered by loess, overlying the weathering products of limestone. From the steepest slope sections the loess cover has been eroded or has not even accumulated. Therefore, the (weathering residue of) limestone outcrops. These are mostly protected areas, preserving the native vegetation cover, with farming activities precluded (Figure 3, Table 1).

Profile $1\left(45^{\circ} 52^{\prime} 45.19^{\prime \prime} \mathrm{N}, 18^{\circ} 18^{\prime} 57.67^{\prime \prime} \mathrm{E}\right)$ was excavated in the Meleg-mál vineyard, located in a relatively gently sloping summit position covered by loess deposits (soil parent material). The upper section and the most convex segment of the slope is covered by Endocalcaric Cambisol (Siltic, Ochric) (IUSS Working Group 2015) (Figure 3, a; Table 1, Profile 1). The texture in the entire soil profile is typical of soils formed on loess deposits, i.e. mainly silty loam.

Profile $2\left(45^{\circ} 53^{\prime} 06.2^{\prime \prime} \mathrm{N}, 18^{\circ} 13^{\prime} 53.7^{\prime \prime} \mathrm{E}\right)$ was excavated South of the village of Csarnóta, East

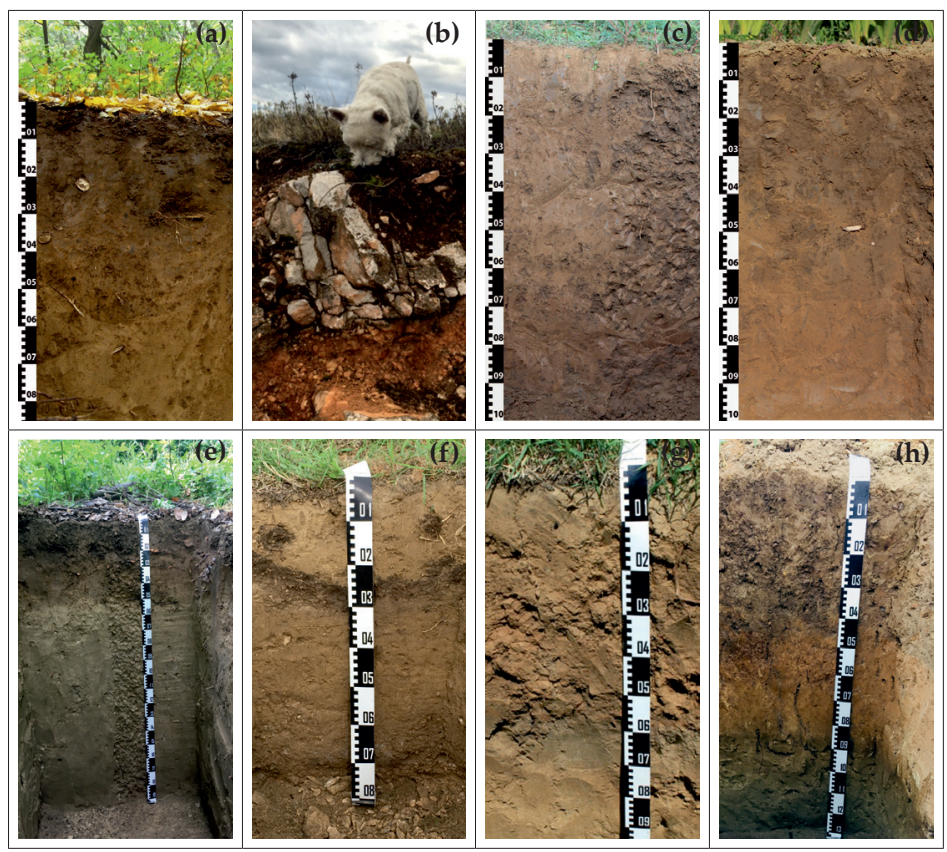

Fig. 3. Representation of the four profiles used for catena characterization (upper photos): Meleg-mál (a); Kopasz Hill, Csarnóta (b); Városi-hegy vineyard (c); Zuhánya vineyard (d); and the four profiles used for verification (lower photos): Ördög-árok (e); Göntér (f); Fekete-hegy, Vylyan winery (g); Kopár (h) 


\begin{tabular}{|c|c|c|c|c|c|c|c|c|}
\hline 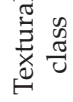 & 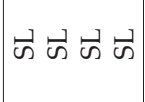 & ळळ & 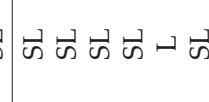 & らம் & 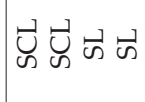 & 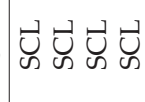 & $\vec{\omega} \leadsto \vec{\omega}\lrcorner 1$ & 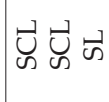 \\
\hline 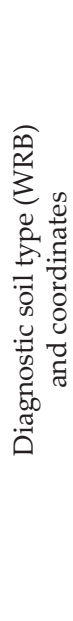 & 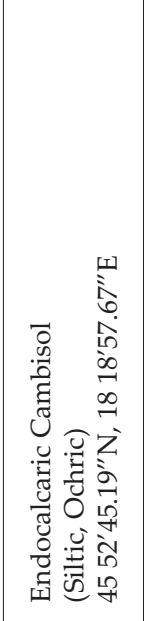 & 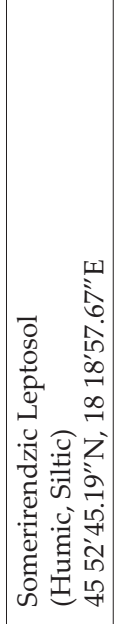 & 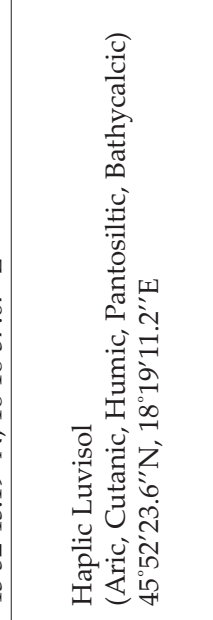 & 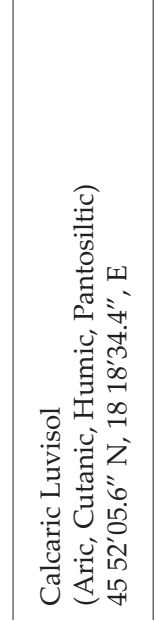 & 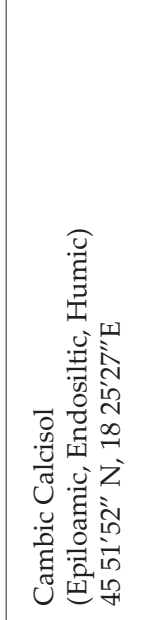 & 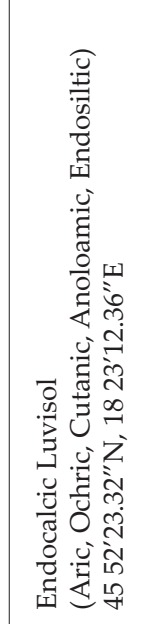 & 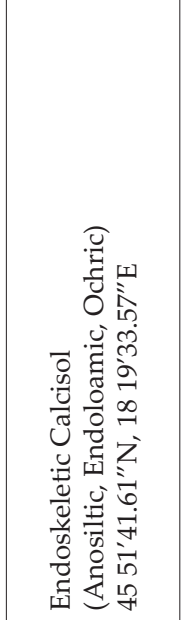 & 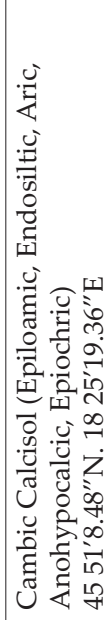 \\
\hline 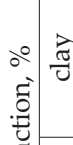 & 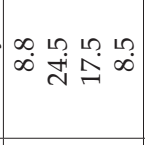 & 루 & 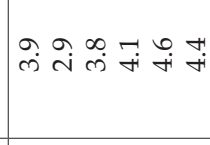 & 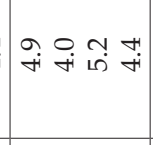 & 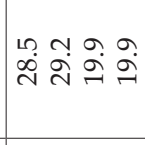 & 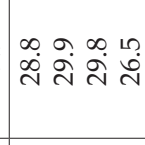 & 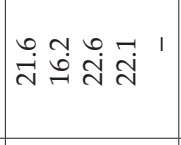 & 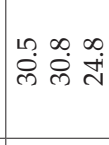 \\
\hline 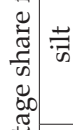 & مُ & 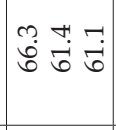 & 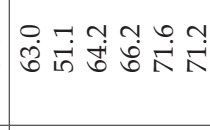 & 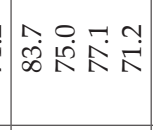 & 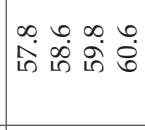 & $\begin{array}{l}\text { na } 0.0 \\
\text { in in in }\end{array}$ & 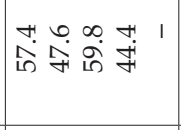 & 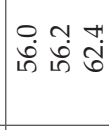 \\
\hline 总 & 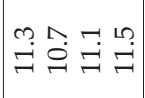 & 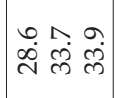 & تُ & 芦完全芒 & ڤ̆ & 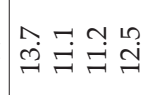 & 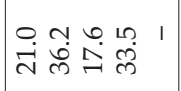 & 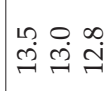 \\
\hline 死 & 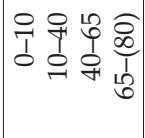 & 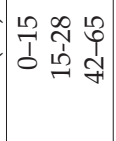 & 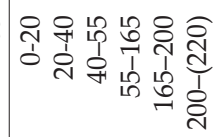 & 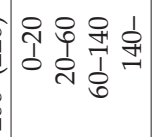 & 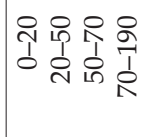 & 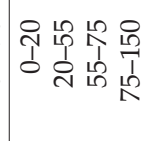 & 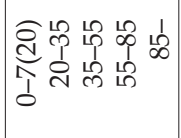 & 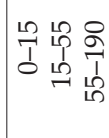 \\
\hline 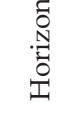 & 存录品 U & 运学悹 & 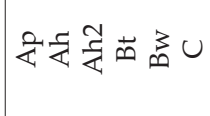 & 妾安茂U & 至光 & 尽苾完 & च̌ & 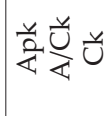 \\
\hline 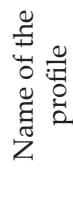 & 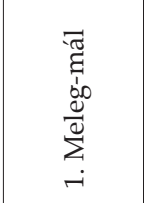 & 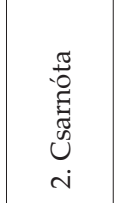 & 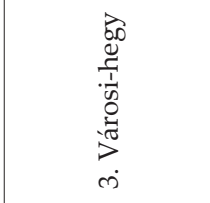 & 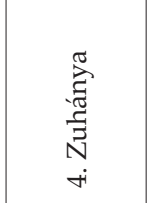 & 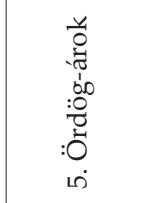 & $\begin{array}{l}\frac{5}{2} \\
\frac{5}{2} \\
6\end{array}$ & 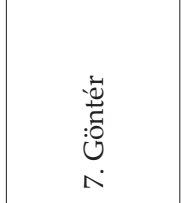 & $\overbrace{2}^{2}$ \\
\hline
\end{tabular}


of Kopasz Hill, on a karstic surface with limestone blocks on surface, at the edge of a quarry, with the surface above having an inclination of $3^{\circ}$ at an elevation of $191 \mathrm{~m}$ (Figure 3, b; Table 1, Profile 2). Due to the shallow topsoil, the soil is classified as Somerirendzic Leptosol (Humic, Siltic). Particle size distribution is dominated by silt and partly by clays, classified as silt loam. Highest clay contents are observed in the $\mathrm{B}_{\mathrm{w}}$ and $\mathrm{BC}$ horizons. Profile 2 represents a soil developed on limestone outcrops (qualifier Rendzic) and its clayey weathering products, containing sand and silt fraction with silty loam texture throughout. The most important feature of the profiles is the presence of coarse fragments in the subsoil and the shallow, carbonate-rich, humic surface epipedon. Soil depth in the vicinity of the profile is highly variable, but generally less than $55 \mathrm{~cm}$.

Profile 3 (4552'23.6"N; 18¹9'11.2” E) was excavated in the Városi-hegy in a midslope position with SSE aspect and an inclination of $5^{\circ}$ at an elevation of $154 \mathrm{~m}$ (Figure 3, c; Table 1, Profile 3). In terms of land use this had been a vineyard until 2001, when it was left fallow. The soil is classified as Haplic Luvisol (Aric, Cutanic, Humic, Pantosiltic, Protocalcic) with silt loam texture. Clay accumulation characterizes the profile below the depth of $40 \mathrm{~cm}$. It is a Haplic Luvisol (Aric, Cutanic, Humic, Pantosiltic, Bathycalcic) developed predominantly on colluvic material and reworked loess-paleosol deposits. The profile was excavated in an abandoned vineyard where cultivation ceased in 2002. The profile indicates a certain degree of leaching and clay translocation, texture is dominated by the silt fraction (Pantosiltic). Since this part of the Villány Hills has been cultivated for the longest time, redeposited sediments accumulated by both natural slope processes and viticulture practiced since Roman times (Aric).

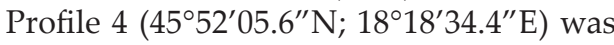
excavated in an actively cultivated vineyard on a very gentle slope inclination of $3^{\circ}$ at an elevation of $124 \mathrm{~m}$ in foothill position (Figure 3, d; Table 1, Profile 4). Classified as a Calcaric Luvisol (Aric, Cutanic, Humic, Pantosiltic) similar to Profile 3, it represents a relatively young soil developed as a consequence of colluvic accumulation (supplementary qualifier Colluvic), transported from upslope by erosion since the area was arable land in the past (Aric) (Lovász, Gy. 1977; Tengler, T. 1997; Czigány, Sz. 1998). The texture of slope deposits is mainly silt (Pantosiltic). The colluvic material has a humic character in the entire profile, probably due to the erosion of topsoil further upslope.

Two profiles out of the four soil profiles used for verification purposes are located in foothill position: Kopár and Ördög-árok. Yet they have a relatively shallow soil of about $50 \mathrm{~cm}$, underlain by loess deposits (see Table 1). For the Kopár, the actual topsoil had a depth of only 5 to $15 \mathrm{~cm}$. The soil profile in the Vylyan vineyard (Table 1, Profile 6) is in mid-slope position with a soil depth of $55 \mathrm{~cm}$ and with a buried topsoil between 55 and $75 \mathrm{~cm}$. Oddly, the Göntér profile (Table 1, Profile 7), despite its plateau (summit) position exposed a heavily ploughed and relatively shallow soil with limestone boulders already occurring at a depth of $55 \mathrm{~cm}$.

\section{Characterization of the pedosequence}

The typical pedosequence of the Villány Hills (Figure 4) was generated by the parent materials (limestone, loess and colluvium), topography and subsequently modified by agricultural activities and natural erosional processes. With the exception of Profile 1, the properties of all analysed profiles, were strongly influenced by human-induced erosion. (Profile 1 is a fairly natural profile on a very gentle slope of the plateau. Erosional processes did not remove the loess cover completely, only inhibited deeper soil development and organic carbon accumulation. Profile 2 is located in the erosional section of the investigated slope. The shallow soils here are discontinuous and scattered, altering with rock outcrops without any soil cover. Formerly, Profile 2 may have also been covered by loess, but we may also deduce that dust deposition itself was not possible here due to steep slopes, and soils have always developed on weathering products of limestone (Leptosols). 


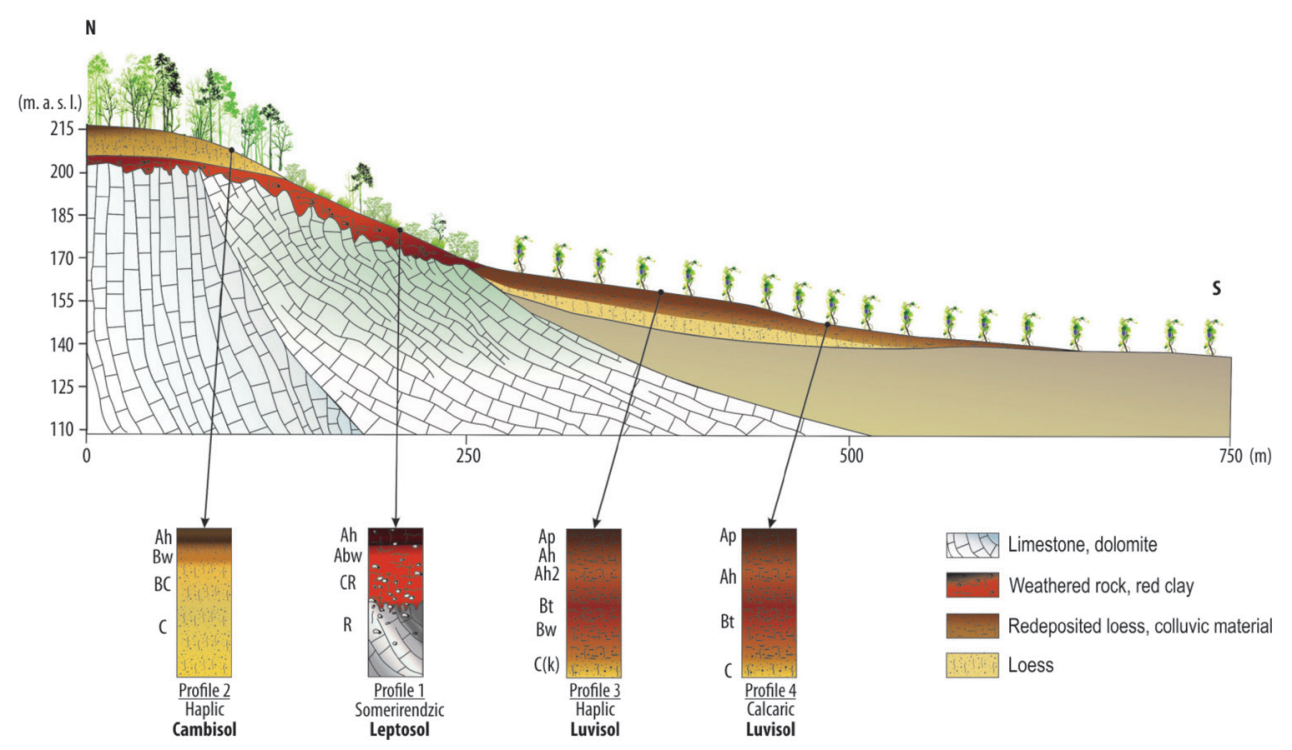

Fig. 4. Typical topographic pedosequence of the southern slopes of the Villány Hills (by CzIGÁnY, Sz. and Novák, T.J.)

Nevertheless, the presence of former and existing Cambic $\mathrm{B}_{\mathrm{w}}$ or even Argic $\mathrm{B}_{\mathrm{t}}$ horizons is also possible in the case of thicker weathered material, which could be eroded later as a consequence of human influence (deforestation, grazing etc.). Today Profile 2 is heavily eroded: the shallow topsoil may have been truncated. Intense derasional processes must have occurred here in the past, probably due to land use (quarrying, vineyards), but also for natural reasons (steep slope, lack of dense forest cover). However, lately, over the past decades, no tillage has been practiced.

Soils developed on redeposited colluvial deposits dominate the middle and lower sections of slopes (profiles 3 and 4). Currently, slope processes have been restrained by grass vegetation and no-till viticulture, which also leads to organic matter enrichment. In Profile 4 humus accumulation was detected in the pedon - probably due to manuring and mineral fertilization.

The impact of erosion, horizontal translocation and re-deposition according to slope position is reflected in the systematic sequence of the described soils. Profile 1 has been markedly eroded and truncated. Therefore, profile development is poor and it was classified as a Cambisol. Profile 2 with shallow Humic and Calcic horizons, but a significant amount of coarse limestone fragments, was classified as Leptosol. Profiles 3 and 4 are both colluvial soils classified as Luvisols. Marked human impact is clearly visible in Profiles 2, 3 and 4, as their upper sections have been eroded, redeposited and transformed into material with coarse granular structure.

\section{Spatial pattern of climate data}

The weighted and interpolated map of the HI indicated the marked insolation and temperature variations as a function of slope aspect and elevation. Although elevation differences are limited and relief is subdued in the Villány Hills, topography still has a profound impact on temperature distribution.

Due to the globally observed increasing temperatures heat indices have regularly exceeded the preferred range of the commonly 
grown grape varieties of the Villány region over the past years. That was especially true for the relatively warm year of 2013. HIs of 2013 commonly exceeded $21^{\circ} \mathrm{C}$-day on the southern slopes of the Villány Hills. These are markedly higher than the preference of the commonly grown grape varieties of the Villány region (Figure 5).

Mean HIs ranged between 1,749 and 2,060 degree-hours for the studied 10 vineyards (Table 2). The lowest value was found for the Várerdő vineyard located in the northeastern foreground of the Szársomlyó Hill. The highest value was found in the Kopár vineyard in the south-eastern footslopes of the Szársomlyó. Vineyards in plateau positions, despite their somewhat higher altitude, still had high HIs around 2,000 degree-hours. Csicsó-hegy was the only exception among the vineyards in plateau positions, with a mean HI of 1,896 .

\section{Spatial distribution of topographic parameters}

Aspect played an important role on the selection of the studied vineyards. Aspect shows a great variability among the studied vineyards. The Várerdo" vineyard had the theoretically less favoured WNW average aspect, with a range from SE to NNW (Table 3). The
Table 2. Spatial statistics of the Huglin Index for the ten studied vineyards

\begin{tabular}{l|c|r|c}
\hline \multicolumn{1}{c|}{ Vineyard } & \multicolumn{1}{c|}{ Mean } & \multicolumn{1}{c|}{ STD } & Median \\
\hline Hársos & $1,983.83$ & 84.87 & 1,987 \\
Várerdő & $1,749.81$ & 60.97 & 1,716 \\
Fekete-hegy & $1,966.20$ & 103.22 & 1,978 \\
Kopár & $2,060.50$ & 51.34 & 2,093 \\
Csillag-völgy & $1,959.49$ & 83.00 & 1,963 \\
Ördög-árok & $1,943.83$ & 158.58 & 1,994 \\
Imre-völgy & $1,949.16$ & 100.49 & 1,953 \\
Mandolás & $2,003.55$ & 72.41 & 2,009 \\
Makár & $2,005.02$ & 65.85 & 1,998 \\
Csicsó-hegy & $1,900.54$ & 100.87 & 1,896 \\
\hline
\end{tabular}

Mandolás, Makár, Hársos, Csicsó-hegy and Kopár vineyards face almost exactly to the South, however, the first four of them essentially found in plateau position with relatively gentle slopes.

In the Villány Hills the elevations of vineyards range from 100 to $279 \mathrm{~m}$ (Table 4). Higher elevations have a lower chance of frost damage in cold winters. In two consecutive winters of 1985-1987 frost severely affected large areas at the foothills. Similarly, lower elevations, due to higher relative humidity values, have a larger potential for fungal diseases. Elevation ranges are up to $132 \mathrm{~m}$. Summit vineyards and Kopár have the lowest range. Kopár is located lowest (122 m) and Csicsó-hegy is the highest (234 m).

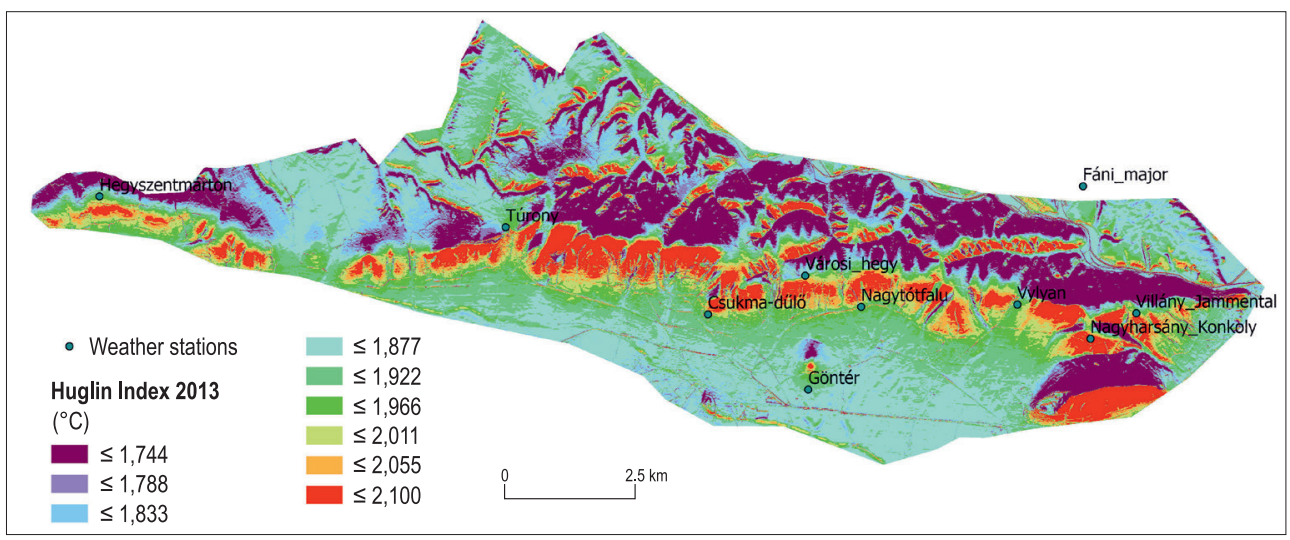

Fig. 5. Spatial distribution of the Huglin Index in the studied area 
Table 3. Spatial statistics of aspect for the ten studied vineyards

\begin{tabular}{l|r|c|c|c|c|c}
\hline \multicolumn{1}{c|}{ Vineyard } & Min, $^{\circ}$ & Max, $^{\circ}$ & Range, $^{\circ}$ & Mode, $^{\circ}$ & Mean, $^{\circ}$ & Abs 180-mean, $^{\circ}$ \\
\hline Hársos & 2.29 & 297.76 & 295.47 & 177.96 & 177.95 & 2.05 \\
Várerdő & 212.47 & 341.57 & 129.09 & 284.18 & 297.24 & 117.24 \\
Fekete-hegy & 175.24 & 316.91 & 141.67 & 191.00 & 192.02 & 12.02 \\
Kopár & 147.99 & 209.05 & 61.06 & 176.67 & 180.61 & 0.61 \\
Csillag-völgy & 0.00 & 357.09 & 357.09 & 176.18 & 177.40 & 2.60 \\
Ördög-árok & 7.13 & 325.01 & 317.88 & 154.71 & 164.85 & 15.15 \\
Imre-völgy & 50.71 & 206.03 & 155.32 & 175.84 & 175.81 & 4.19 \\
Mandolás & 132.34 & 247.89 & 115.55 & 176.68 & 173.33 & 6.67 \\
Makár & 120.43 & 225.00 & 104.57 & 175.55 & 171.12 & 8.88 \\
Csicsó-hegy & 0.00 & 345.96 & 345.96 & 197.07 & 195.18 & 15.18 \\
\hline
\end{tabular}

Table 4. Spatial statistics of elevation for the ten studied vineyards

\begin{tabular}{l|c|c|c|c|c|c}
\hline \multicolumn{1}{c|}{ Vineyard } & Min, $\mathrm{m}$ & Max, $\mathrm{m}$ & Range, $\mathrm{m}$ & Mean, $\mathrm{m}$ & STD & Median, $\mathrm{m}$ \\
\hline Hársos & 147 & 235 & 88 & 195.76 & 24.29 & 200 \\
Várerdő & 130 & 223 & 93 & 168.21 & 22.81 & 167 \\
Fekete-hegy & 141 & 268 & 127 & 185.54 & 27.73 & 181 \\
Kopár & 100 & 162 & 62 & 121.59 & 14.61 & 121 \\
Csillag-völgy & 141 & 273 & 132 & 197.25 & 40.15 & 187 \\
Ördögárok & 149 & 279 & 130 & 215.71 & 34.36 & 217 \\
Imre-völgy & 110 & 213 & 103 & 155.70 & 30.81 & 148 \\
Mandolás & 136 & 200 & 64 & 159.08 & 15.27 & 156 \\
Makár & 123 & 200 & 77 & 148.64 & 15.46 & 144 \\
Csicsó-hegy & 200 & 250 & 50 & 233.57 & 12.01 & 235 \\
\hline
\end{tabular}

Generally, mean slope inclination remained below $10^{\circ}$ for 9 of the studied vineyards, with the exception of Ördög-árok, where mean slope inclination reached $11.54^{\circ}$ (Table 5). Vineyards in plateau positions generally had a mean slope inclination of less than $6^{\circ}$, hence they are preferred for viticulture.

\section{Spatial correlations among terroir factors and must properties}

The current study revealed the effect of HI, elevation, slope, aspect and soil on grape juice properties for 10 selected vineyards in the Villány Hills (Table 6). Elevation and slope did not show correlation with any of the VVC parameters. $\mathrm{HI}$ and aspect had a moderate linear relationship with 5 VVC parameters with $r^{2}$ ranging between 0.5045 and 0.6954 . HI showed a correlation with four nitrogen related parameters (FAN, $\mathrm{NH}_{3^{\prime}}$ YAN), density and glucose + fructose content, while aspect showed moderate correlation with PAN. Aspect, when determined on the basis of angular distance from South $\left(180^{\circ}\right)$ showed a strong correlation $\left(r^{2}>0.7\right)$ with FAN, $\mathrm{NH}_{3^{\prime}}$ YAN, sugar content (fructose + glucose) and density.

Based on cluster analysis of all studied parameters (terroir and VVC parameters), three vineyard clusters were identified (Figure 6). The Várerdö vineyard with dominantly NW, NNW (297 $)$ facing slopes forms an outlier. The second cluster included the Csillag-völgy, Imre-völgy, Ördög-árok and Csicsó-hegy. In this latter cluster vineyards are characterized by relatively high relief and large topographical differences, with medium HIs. The third cluster, encompassing the Fekete-hegy, Hársos, Makár, Mandolás and Kopár vineyards included areas with the relatively low relief and high indices. In this cluster Fekete-hegy is located on gentle slopes, Kopár in a foothill position while the remaining three are positioned on flat summits in the central section of the range. 
Table 5. Spatial statistics of slope for the ten studied vineyards

\begin{tabular}{l|c|c|c|c|c}
\hline \multicolumn{1}{c|}{ Vineyard } & Min, $^{\circ}$ & Max $^{\circ}$ & Range, $^{\circ}$ & Mean, & STD \\
\hline Hársos & 0.45 & 10.42 & 9.97 & 4.86 & 2.00 \\
Várerdő & 1.23 & 21.95 & 20.72 & 7.88 & 4.16 \\
Fekete-hegy & 1.23 & 15.72 & 14.49 & 5.80 & 3.02 \\
Kopár & 1.47 & 21.96 & 20.49 & 7.77 & 3.77 \\
Csillag-völgy & 1.03 & 14.01 & 12.98 & 5.29 & 2.23 \\
Ördög-árok & 1.01 & 22.16 & 21.15 & 11.54 & 4.82 \\
Imre-völgy & 1.62 & 15.12 & 13.50 & 5.75 & 2.67 \\
Mandolás & 1.72 & 10.51 & 8.80 & 5.52 & 2.17 \\
Makár & 1.87 & 15.62 & 13.75 & 6.02 & 3.16 \\
Csicsó-hegy & 0.81 & 13.10 & 12.29 & 4.97 & 2.13 \\
\hline
\end{tabular}

Table 6. Coefficients of correlation $\left(r^{2}\right)$ of various VVC parameters with HI, elevation, slope inclination and aspect for the ten studied vineyards

\begin{tabular}{l|c|c|c|c}
\hline \multicolumn{1}{c|}{ Parameters } & HI & Elevation & Slope & Aspect \\
\hline Tartaric acid & 0.1664 & 0.2183 & 0.0984 & 0.0339 \\
$\mathrm{pH}$ & 0.1341 & 0.2182 & 0.1105 & 0.0152 \\
Malic acid & 0.2657 & 0.0187 & 0.1122 & 0.4867 \\
Primary amino nitrogen (PAN) & 0.3671 & 0.0107 & 0.0670 & 0.5766 \\
Free amino nitrogen (FAN) & 0.5045 & 0.0099 & 0.0232 & $\mathbf{0 . 8 0 3 0}$ \\
$\mathrm{NH}_{3}$ & 0.5865 & 0.0573 & 0.0604 & $\mathbf{0 . 7 9 5 7}$ \\
Yeast assimilable nitrogen (YAN) & 0.5715 & 0.0288 & 0.0036 & $\mathbf{0 . 8 7 1 8}$ \\
Density & 0.5841 & 0.0263 & 0.0225 & $\mathbf{0 . 8 8 0 9}$ \\
Bx & 0.2389 & 0.0449 & 0.1262 & 0.4092 \\
Glucose + fructose & 0.5609 & 0.0061 & 0.0016 & $\mathbf{0 . 8 5 4 7}$ \\
\hline
\end{tabular}

Note: Moderate and strong linear relationships.

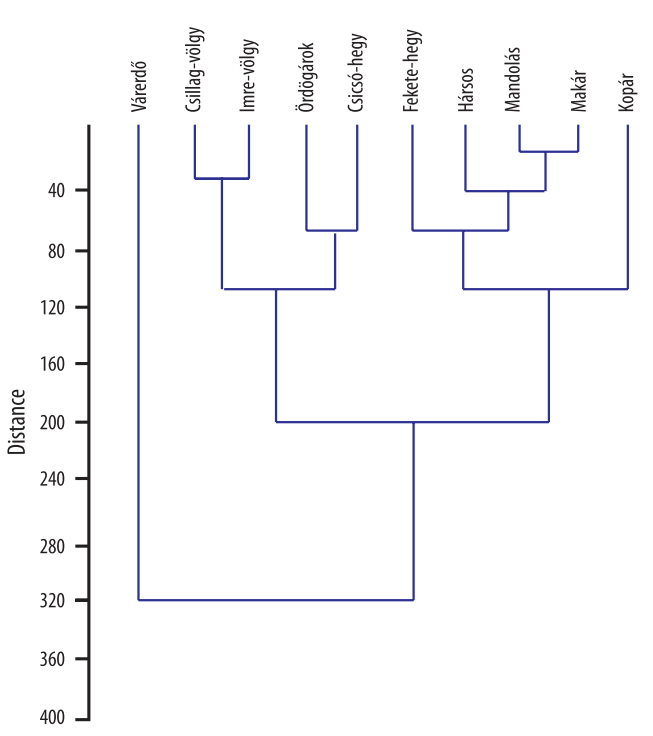

Fig. 6. Cluster analysis of the studied vineyards based on all studied parameters

\section{Conclusions}

The complexity of a terroir calls for a holistic approach to grabbing its essence. Former literature has pointed out significant spatial differences in pedological and topographical properties within single vineyards, with a subsequent spatial variability on the growth and development of the vine shoots, berries as well as grape quality (e.g. CHeng, G. et al. 2014; BAlla, D.Z. et al. 2019). Although the topography and morphology of the Villány Hills are relatively simple, in accordance with the findings of former works (e.g. Ough, C.S. and Kriel, A. 1985; Ubalde, J.M. et al. 2010; Petrovic, G. et al. 2019), our results revealed a relationship among topographical properties (elevation, aspect and slope), soil variability and selected chemical properties of the grape juice. Hence, alongside the spatial patterns of management techniques (Coller, E. et al. 
2019), the infinite combinations of biophysical factors generate a great diversity of terroirs in the area. Explaining the distribution of rocks, slopes, soils, water availability, microclimate and natural vegetation, in our opinion, the topographic pedosequence is an equally complex concept, which is capable of reflecting many of the essential properties of a terroir.

Nonetheless, functional relationship has only partially been found between the various abiotic and chemical properties. The probable reason for this is the complex influence of abiotic factors on must quality, and, in general, on the physiology of the grape. Therefore, the terroir cannot be broken down into a series of individual indicators. Favouring relatively gentle slopes and considerable soil depths, the majority of the studied vineyards are found in either foothill or plateau positions. This heterogeneous topographical distribution, is found to be at least partially reflected in VVC chemical properties, including FAN, $\mathrm{NH}_{3}$, YAN, sugar content and density. Soils of the Villány Hills, found on plateaus and foothill positions tend to have deeper root systems and grow on a soils of higher organic matter content, as organic matter either remain non-transported (plateaus) or is transported to the gentle slopes of foothill positions (KENDERESSY, P. and Lieskoskŕ, J. 2014; Kirchhoff, M. et al. 2014). Equivocally with the results of TARDAGuila, J.et al. (2011), soils in the southern slopes of the Villány Hills, mixed with colluvial sediments in foothill positions tend to have higher clay contents therefore likely have a higher cation exchange capacity and more plant available moisture contents.

Further upslope, however, above the zone of colluvial materials, organic matter and clay contents tend to decrease, reaching the lowest values in the zone of inflection. Nonetheless, vertical variation of this sort is likely occur in soils developing along a toposequence, where the prevailing soil forming factor is topography, discussed in details by e.g. Meinert, L. and Busacca, A. (2002), REPE, B. et al. (2017) and VRščAJ, B. et al. (2017). This type of spatial pattern of soil qualities generates more fertile soils with clay-loamy textures and higher water holding and supplying capacities at footslope positions whereas fertility and mean moisture contents decrease with increasing elevations (Busacca, A. and Meinert, L. 2003). However, in correspondence with the findings of Wilkins, D. and Busacca, A. (2017) obtained under similar climatic and topographic conditions to those of the Villány Hills, we also concluded that local meso- and microclimate, and in general geodiversity (STEPIŠNIK, U. et al. 2017) may significantly influence the locality-specific terroir properties and wine quality through the spatial pattern of soil properties.

Acknowledgement: The authors are grateful to Ignác Ruppert (Cellarius Commercial House Ltd., Pécs) for providing viticultural data and to the National Office for Research, Development and Innovation (NKFIH) for financial support within the Programme Excellence in Higher Education Institutions 2019, Topic II. 3. ("Innovation for sustainable life and environment"). Tibor József Novák is grateful for funding provided by the János Bolyai Scholarship and the new national excellence program of the Ministry for Innovation and Technology.

\section{REFERENCES}

Balla, D.Z., Kozics, A., Mester, T., Mikita, T., IncZe, J., Novék, T. and Zichar, M. 2019. A GIS tool to express soil naturalness grades and geovisualization of results on Tokaj Nagy-Hill. Acta Polytechnica Hungarica 16. (6): 191-205. Doi: 10.12700/aph.16.6.2019.6.12

Barata, A., Malfeito-Ferreira, M. and Loureiro, V. 2012. The microbial ecology of wine grape berries. International Journal of Food Microbiology 153. (3): 243-259. Doi: 10.1016/j. ijfoodmicro.2011.11.025

Baskan, O., Dengiz, O. and Gunturk, A. 2016. Effects of toposequence and land use-land cover on the spatial distribution of soil properties. Environmental Earth Sciences 75. 448-458. Doi: 10.1007/s12665016-5301-6

Biancotti, A. 2003. Physical geography's contribution to studying terroir. In Spaces, Environments and Landscapes of Terroirs. Eds.: BiancotTI, A., Pambianchini, G. and Pioletti, A.M., Milano, BEM, Stefano Bianchi, 11-16.

Borden, R.W., Baillie, I.C. and Hallett, S.H. 2020. The East African contribution to the formalisation 
of the soil catena concept. Catena 185 . Article 104264. Doi: 10.1016/j.catena.2019.104291

Borhidi, A. and Dénes, A. 1997. The rock sward communities of the Mecsek and Villány Mts. Studia Phytologica Jubilaria, Pécs, University of Pécs, 45-66.

Вӧткӧs, T. 2006. Precipitation trends in Pécs. In Pollution and Water Resources. Ed.: Halasy-Kun, G., New York, Columbia University Seminars XXXVI. 171-178.

Bramley, R. and Hamilton, R. 2007. Terroir and precision viticulture: are they compatible? OENO One 41. (1): 1-8. Doi: 10.20870/oeno-one.2007.41.1.855

Busacca, A. and Meinert, L. 2003. Wine and geology The terroir of Washington State. In GSA Field Guide 4: Western Cordillera and Adjacent Areas, Ed.: SwAnson, T.W., Boulder, CO, USA, Geological Society of America, 69-85. Doi: 10.1130/0-8137-0004-3.69.

Cheng, G., He, Y.N., Yue, T.X., WAng, J. and Zhang, ZH.W. 2014. Effects of climatic conditions and soil properties on Cabernet Sauvignon berry growth and anthocyanin profiles. Molecules 19. (9): 13683-13703. Doi: 10.3390/molecules190913683

Choné, X., van Leeuwen, C., Chéry, P. and RibéreauGayon, P. 2001. Terroir influence on water status and nitrogen status of non irrigated CabernetSauvignon (Vitis vinifera): vegetative development, must and wine composition. South African Journal of Enology and Viticulture 22. (1): 8-15. Doi: 10.21548/22-1-2159

Coller, E., Cestaro, A., Zanzotti, R., Bertoldi, D., Pindo, M., Larger, S., Albanese, D., Mescalchin, E. and Donati, C. 2019. Microbiome of vineyard soils is shaped by geography and management. Microbiome 7. 140-155. Doi: 10.1186/s40168-019-0758-7.

Czigány, Sz. 1997. Analysis of the loess profile in Beremend, SW Hungary. Földrajzi Értesitö / Hungarian Geographical Bulletin 46. (1-2): 97-103. (in Hungarian with English abstract)

CZIGÁnY, Sz. 1998. Contribution to the denudation processes of the southern slopes of Villány Hills during Late Pleistocene and Holocene. Földrajzi Értesitő / Hungarian Geographical Bulletin 47. (2): 123-129. (in Hungarian with English abstract)

Czigány, Sz. and Nagyváradi, L. 2000. A természeti és társadalmi tényezők kölcsönhatása a Villányi borvidéken löszkémiai vizsgálatok alapján (Interactions between the physical and social factors in the Villány wine region based on chemical analyses of loess). In Területfejlesztés - regionális kutatások. Eds.: Lovász, Gy. and Szabó, G., Pécs, PTE TTK Földrajzi Intézet, 63-72. (in Hungarian)

Czigány, Sz., Fábián, Sz.Á., Nagy, G. and Novák, T.J. 2018. Soils of the southern slopes of the Villány Hills, SW Hungary. In Soil Sequences Atlas II. Eds.: Świtoniak, M. and Charzyński, P., Toruń, Poland, Machina Druku, 187-200.

Dezsô, J., Sebe, K. and Horváth, G. 2004. Villányihegység útikalauz (A guide to the Villány Hills). Pécs,
JPTE Barlangkutató. (in Hungarian with English summaries)

Deloire, A., Vaudour, E., Carey, V.A., Bonnardot, V. and van LeEUWEN, C. 2005. Grapevine responses to terroir: A global approach. Journal International des Sciences de la Vigne et du Vin 39. (4): 149-162. Doi: 10.20870/oeno-one.2005.39.4.888

FAlcetti, M. 1994. Le terroir. Qu'est-ce qu'un terroir? Pourquoi l'étudier? Pourquoi l'enseigner? Bulletin O.I.V. 67. 246-275.

Ferretti, C.G. 2019. Relationship between the geology, soil assessment, and terroir of Gewürtztraminer vineyards: A case study in the Dolomites of northern Italy. Catena 179. 74-84. Doi: 10.1016/j. catena.2019.03.044

Fraga, H., Malheiro, A.C., Moutinho-Pereira, J. and SAnTos, J.A. 2013. Future scenarios for viticultural zoning in Europe: ensemble projections and uncertainties. International Journal of Biometeorology 57. 909-925. Doi: 10.1007/s00484-012-0617-8

Fraga, H., Malheiro, A.C., Moutinho-Pereira, J., Cardoso, R.M., Soares, P.M., Cancela, J.J., Pinto, J.G. and SANTOS, J.A. 2014. Integrated analysis of climate, soil, topography and vegetative growth in Iberian viticultural regions. PLoS One 9. (9): e108078. Doi: 10.1371/journal.pone.0108078

Fraga, H., Costa, R. and Santos, J. 2018. Modelling the Terroir of the Douro Demarcated Region, Portugal. E3S Web of Conferences 50: 02009. XII Congreso Internacional Terroir. Doi: 10.1051/ e3sconf/20185002009

GABEL, B. 2019. New concept of vine grape protection - knowledge-based approach $\mathcal{E}$ high tech. $42^{\text {nd }}$ World Congress of Vine and Wine, 15-19 July 2019 Geneva, Switzerland. BIO Web Conferences 15: 01020. Doi: 10.1051/bioconf/20191501020

Gilbert, J.A., van der Lelie, D. and Zarraonaindia, I. 2014. Microbial terroir for wine grapes. Proceedings of the National Academy of Sciences 111. 5-6. Doi: $10.1073 /$ pnas. 1320471110

Gladstones, J. 2011. Wine, Terroir and Climate Change. Mile End (South Australia), Wakefield Press.

Guidelines for soil description 2006. Rome, FAO.

Hall, A., Lamb, D.W., Holzapfel, B. and Louis, J. 2002. Optical remote sensing applications in viticulture - a review. Australian Journal of Grape and Wine Research 8. (1): 36-47. Doi: 10.1111/j.17550238.2002.tb00209.x

Halliday, J. 2007. Wine Atlas of Australia. Oakland, CA, University of California Press.

HAYNES, S.J. 2000. A geological foundation for terroirs and potential sub-appelations of Niagara Peninsula wines, Ontario, Canada. Geology and wine series 2. Geoscience Canada 27. 67-87.

Hilbert, G., Soyer, J.-P., Molot, C., Giraudon, J., Milin, S. and Gaudillère, J.-P. 2003. Effects of nitrogen supply on must quality and anthocyanin accumulation in berries of cv. Merlot. Vitis 42. 69-76. 
Huglin, P. 1986. Biologie et écologie de la vigne. Paris, Lavoisier.

IUSS Working Group 2015. World Reference Base (WRB) for soil resources 2014. Update 2015. International soil classification system for naming soils and creating legends for soil maps. World Soil Resources Report No 106. Rome, FAO.

JACKSON, D. and LoMBARD, P. 1993. Environmental and management practices affecting grape composition and wine quality - a review. American Journal of Enology and Viticulture 44. 409-430.

Jones, G.V., Snead, N. and Nelson, P. 2004. Geology and wine 8. Modeling viticultural landscapes: A GIS analysis of the terroir potential in the Umpqua Valley of Oregon. Geoscience Canada 31. 167-178.

Jordán, Gy., van Rompaey, A., Szilassi, P., Csillag, G., Mannaerts, C. and Woldai, T. 2005. Historical land use changes and their impact on sediment fluxes in the Balaton basin (Hungary). Agriculture, Ecosystem \& Environment 108. (2): 119-133. Doi: 10.1016/j.agee. 2005.01.013

Kenderessy, P. and Lieskoský, J. 2014. Impact of the soil erosion on soil properties along a slope catena - Case study of Horný Ohaj vineyards, Slovakia. Carpathian Journal of Earth and Environmental Sciences 9. (2): 143-152.

Kirchhoff, M., Rodrigo-Comino, J., Seeger, M. and RIES, J.B. 2017. Soil erosion in sloping vineyards under conventional and organic land use managements (Saar-Mosel Valley, Germany). Cuadernos de Investigación Geográfica 43. (1): 119-140. Doi: doi. org/10.18172 /cig.3161

Kottek, M., Grieser, J., Beck, C., Rudolf, B. and RubeL, F. 2006. World map of Köppen-Geiger climate classification updated. Meteorologische Zeitschrift 15. (3): 259-263. Doi: 10.1127/0941-2948/2006/0130

Lovész, Gy. 1973. Geomorphological development of the Villány Mountains. Studia Geomorphologica Carpato Balcanica 7.1-7.

Lovász, Gy. 1977. Baranya megye természetföldrajza (Physical geography of Baranya County). Pécs, Baranya Megyei Levéltár. (in Hungarian)

Lovász, Gy. and Wein, Gy. 1974. A Dél-Dunántúl természetföldrajza (Physical geography of the Southern Transdanubia). Pécs, Baranya Megyei Levéltár. (in Hungarian)

Lóczy, D. and Nyizsalovszki, R. 2005. Borvidékek földhasználat-változásainak tájökológiai értékelése (Landscape ecological assessment of land use changes in the wine regions of Hungary). Tájökológiai Lapok 3. 243-252. (in Hungarian)

Mackenzie, D.E. and Christy, A.G. 2005. The role of soil chemistry in wine grape quality and sustainable soil management in vineyards. Water Science and Technology 51. 27-37. Doi: 10.2166/wst.2005.0004

Malheiro, A.C., Santos, J.A., Fraga, H. and Pinto, J.G. 2010. Climate change scenarios applied to viticultu- ral zoning in Europe. Climate Research 43. 163-177. Doi: $10.3354 /$ cr00918

Matthews, M. and Anderson, M. 1988. Fruit ripening in Vitis vinifera L.: responses to seasonal water deficits. American Journal of Enology and Viticulture 39. 313-320.

Matthews, M. and Anderson, M. 1989. Reproductive development in grape (Vitis vinifera L.): responses to seasonal water deficit. American Journal of Enology and Viticulture 40. 52-60.

Meinert, L. and Busacca, A. 2002. Geology and wine 6. Terroir of the Red Mountain Appellation, Central Washington State, U.S.A. Geoscience Canada 29. 149-168.

MiLne, G. 1935. Some suggested units of classification and mapping particularly for East African soils. Bodenkundliche Forschung, Supplement to the Proceedings of the International Union of Soil Science IV. 183-198.

Novák, T.J., Incze, J., Spohn, M., Glina, B. and Giani, L. 2014. Soil and vegetation transformation in abandoned vineyards of the Tokaj Nagy-Hill. Catena 123. 88-98. Doi: 10.1016/j.catena.2014.07.017

OIV 2008. Proposition of a definition of a vitivinicultural terroir. Paris, Organisation International de la Vigne et du Vin.

Ollier, C.D., Webster, R., Lawrance, C.J. and ВеСКетт, P.H.T. 1969. Terrain classification and data storage. Land Systems of Uganda. MEXE Report 959. Christchurch, U.K., MEXE.

Ough, C.S. and Kriel, A. 1985. Ammonia concentrations of musts of different grape cultivars and vineyards in the Stellenbosch Area. South African Journal of Enology and Viticulture 6. (1): 7-11. Doi: 10.21548/6-1-2353

Pansu, M. and Gatheyrou, J. 2006. Handbook of Soil Analysis. Berlin-Heidelberg, Springer Verlag, 35-42. Doi: 10.1007/978-3-540-31211-6

Petrovic, G., Aleixandre-Tudo, J.-L. and Buica, A. 2019. Unravelling the complexities of wine: A big data approach to yeast assimilable nitrogen using InfraRed spectroscopy and chemometrics. OENO One 2. 107-127. Doi: 10.20870/oeno-one.2019.53.2.2371

QI, Y.B., WANG, R., QIN, Q.R. and SUN, Q. 2019. Soil affected the variations in grape and wine properties along the eastern foot of Helan Mountain, China. Acta Agriculturae Scandinavica, Section B. - Soil \& Plant Science 69. (6): 494-502. Doi: 10.1080/09064710.2019.1611914

Radwanski, S.A. and Ollier, C.D. 1959. A study of an East African catena. Journal of Soil Science 10. 149-168. Available at http://www.wossac.com/search/wossac_detail.cfm?ID $=25140$

RePe, B. and Simončıč, P. and VRšČaJ, B. 2017. Factors of soil formation. In The Soils of Slovenia. Eds.: VRščAJ, B., Repe, B. and Simončrč, P., Dordrecht, Springer, 19-60. Doi: 10.1007/978-94-017-8585-3_3. 
Sebe, K. 2017. Structural evolution of the MecsekVillány area (SW Hungary) during post-rift phase and basin inversion. In Abstracts book. $7^{\text {th }}$ International Workshop: Neogene of Central and SouthEastern Europe. Velika, Croatia, 28-31 May 2017. Eds.: Horvat, M. and Wacha, L., Zagreb, Croatian Geological Survey, 60-61.

Seguin, G. 1986. 'Terroirs' and pedology of wine growing. Experientia 42. (8): 861-873. Doi: 10.1007/ BF01941763

Šmid Hribar, M., GeršIč, M., Pipan, P., Repolusk, P., Tiran, J., Topole, M. and Ciglič, R. 2017. Cultivated terraces in Slovenian landscapes. Acta geographica Slovenica 57. (2): 83-97. Doi: 10.3986/AGS.4597

Stepišnik, U., Ilc Klun, M. and Repe, B. 2017. Assessment of educational potential of geodiversity on example of Cerknica Polje, Slovenia. Dela 47 (1): 5-39. Doi: 10.4312/dela.47.1.5-39.

Świtoniak, M., Charzyński, P., Novák, T.J., Zalewska, K. and BEDNAREK, R. 2014. Forested hilly landscape of Bükkalja Foothill (Hungary). In Soil Sequences Atlas. Eds.: Świtoniak, M. and Charzyński, P., Toruń, Nicholaus Copernicus University Press, 169-181.

Szilassi, P., Jordán, Gy., Rompaey, A. and Csillag, G. 2006. Impacts of historical land use changes on erosion and agricultural soil properties in the Káli Basin at Lake Balaton, Hungary. Catena 68. 96-108. Doi: 10.1016/j.catena.2006.03.010

Tagliavini, M. and Rombolà, A.D. 2001. Iron deficiency and chlorosis in orchard and vineyard ecosystems. European Journal of Agronomy 15. (2): 71-92. Doi: 10.1016/S1161-0301(01) 00125-3

Tardaguila, J., Baluja, J., Arpon, L., Balda, P. and Oliveira, M. 2011. Variations of soil properties affect the vegetative growth and yield components of "Tempranillo" grapevines. Precision Agriculture 12. (5): 762-773. Doi: 10.1007/s11119-011-9219-4

Tengler, T. 1997. A természeti környezet antropogén változásai Villány térségében (Antropogenic changes in the physical environment around the town of Villány). Publications from the Department of Physical Geography 4. Pécs, University of Pécs, 1-15. (in Hungarian)

Ubalde, J.M., Sort, X., Zayas, A. and Poch, R.M. 2010. Effects of soil and climatic conditions on grape ripening and wine quality of Cabernet Sauvignon. Journal of Wine Research 21. (1): 1-17. Doi: 10.1080/09571264.2010.495851

Unwin, T. 2012. Terroir: At the heart of geography. In The Geography of Wine: Regions, Terroir and Techniques. Ed.: DougherTy, P.H., Dordrecht, Springer Science \& Business Media, 37-48.

van Leeuwen, C. and Seguin, G. 2006. The concept of terroir in viticulture. Journal of Wine Research 17. 1-10. Doi: 10.1080/09571260600633135

van Leeuwen, C. 2010. Terroir: the effect of the physical environment on vine growth, grape ripening and wine sensory attributes. In Managing Wine Quality. Volume 1: Viticulture and Wine Quality. Ed.: Reynolds, A., Oxford, Woodhead Publishing Ltd., 273-315. Doi: 10.1533/981845699284.3.273.

VAudour, E. 2001. Diversité des notions de terroir. Pour un concept de terroir opérationnel. Revue des Oenologues 101. 39-41.

Vaudour, E. 2002. The quality of grapes and wine in relation to geography: Notions of terroir at various scales. Journal of Wine Research 13: 117-141. Doi: 10.1080/0957126022000017981

Vaudour, E. 2003. Les terroirs viticoles. Définitions, caractérisation, protection. Paris, Dunod.

Vaudour, E., Morlat, R., van Leeunen, C. and Doledec, A.F. 2005. Terroirs viticoles et sols. In Sols et Environnement. Eds.: Girard, M.C., Walter, C., Rémy, J.C. and Berthelin, J., Paris, Dunod, 105-126. VRšČAJ, B., RePE, B. and SimonČıč, P. 2017. Soil degradation. In The Soils of Slovenia. Eds.: VRšČAJ, B., REPE, B. and Simončič, P., Dordrecht, Springer, 171-198. Doi: 10.1007/978-94-017-8585-3_8.

WANG, R., Sun, Q. and CHANG, Q.R. 2015. Soil types effect on grape and wine composition in Helan Mountain area of Ningxia. PlosOne 10. (2): e0116690. Doi: 10.1371/journal. pone.0116690

Warmling, M.T., Albuquerque, J.A., Warmling, M.I., Rufato, L. and Andognini, J. 2018. Effect of soil classes and climatic conditions on the productive characteristics and composition of Cabernet Sauvignon grapes. Revista Brasileira de Fruticultura 40. (6): 1-14. Doi: 10.1590/0100-29452018035.

Wein, Gy. 1967. A Délkelet-Dunántúl szerkezetföldtana (Structural geology of the Southeastern Transdanubian region). Földtani Közlemények 91. 372-395. (in Hungarian)

WiLkins, D. and Busacca, A. 2017. Insights into terroir factors from a dense network of vineyard soil and weather stations, Sunnyslope District, Idaho. Conference Paper. GSA Annual Meeting, Seattle, WA, USA. Doi: 10.1130/abs/2017AM-303829.

WiLson, J. 1998. Terroir, the role of geology, climate and culture in the making of French wines. San Francisco, CA, University Press of California.

Winkler, A.J., Cook, J.A., KLIEwer, W.M. and Lider, L.A. 1974. General Viticulture. Second Revised Edition. Berkeley-Los Angeles, University of California Press.

Wooldridge, J. 2000. Geology: A central aspect of terroir. Wineland 12. 87-90.

Zsófi, Zs., Tóth, E., Rusjan, D. and Bálo, B. 2011. Terroir aspects of grape quality in a cool climate wine region: Relationship between water deficit, vegetative growth and berry sugar concentration. Scientia Horticulturae 127. (4): 494-499. Doi: 10.1016/j.scienta.2010.11. 014. 
